\title{
Monstrosities: Religion, Identity and Belief
}

\author{
Douglas J. Davies ${ }^{1}$ and Michael J. Thate ${ }^{2, *}$ \\ 1 Department of Theology and Religion, Durham University, Stockton Rd, Durham, County Durham DH1, UK; \\ douglas.davies@durham.ac.uk \\ 2 Center for the Study of Religion, Princeton University, Princeton, NJ 08544, USA \\ * Correspondence: Mthate@princeton.edu; Tel.: +1-507-848-5863
}

Received: 17 May 2017; Accepted: 22 May 2017; Published: 23 May 2017

In the summer of 1816, a young woman of nineteen eloped with the poet Percy Bysshe Shelley to Geneva, Switzerland. There they passed the rainy summer evenings with Lord Byron, discussing philosophy and poetry, and experimenting with the telling of ghost stories. The young woman was Mary Shelley. And the "ghost story" she shared with the small Swiss Salon, finished in 1817 though published in 1818, would become the macabre classic, Frankenstein.

In her Introduction to the third edition, written on 15 October 1831, she reflected of her struggle to compose an original idea for the imposing Salon.

Life appeared to me too common-place an affair as regarded myself. I could not figure to myself that romantic woes or wonderful events would ever be my lot; but I was not confined to my own identity, and I could people the hours with creations far more interesting to me at that age, than my own sensations (Shelley [1817] 1998a, p. 6).

After long hours spent peering into the "blank incapability of invention," that "dull Nothing" which terrifies any author (Shelley [1817] 1998a, p. 8), she turned her thinking along "the mysterious fears of our nature," in order to "awaken [a] thrilling horror-one to make the reader dread to look round, to curdle the blood, and quicken the beatings of the heart" (Shelley [1817] 1998a, p. 8).

The relevance of Shelley's Meisterwerk for this special edition reaches beyond the serendipity of its bicentenary. Its provenance and plot raise fundamental questions and problems for each of the topics which organize this special issue: religion, identity, belief and the practices of each. Shelley's narration of her ghost-story's origins reflects an instability within rigidity-a form-of-life too snug for the constellation of sentiments brewing in and all about her. This instability within the rigidities of form-of-life exemplified fundamental fissures in a nineteenth-century western imaginary along the axes of subject location: religion, identity, belief, and their practices.

In her Introduction, the instability and the rigidity receive similes of attribution: "myself," "my own identity," "I," "own," "Life." It was within this form-of-life which both produced the point of self-reflection and the desire to escape from it. The affective quality of an "awakening thrilling horror" was necessary in order to shock the latent instability from within the inherited rigid formations, loosing itself into fresh possibilities of being. And yet, as Victor Frankenstein would painfully discover,

Nothing is so painful to the human mind as a great and sudden change. The sun might shine, or the clouds might lower: but nothing could appear to me as it had done the day before (Shelley [1817] 1998b, p. 197).

The loosing of instability from rigidity recalibrates settled postures of belief and points of view, out of which emerge a thousand little monsters all seeking revenge on their creator.

This special issue attempts to conjure the spirit of Shelley by placing the well-worn descriptors of "belief," "practice," and "identity" in conversation across a broad range of disciplinary approaches in order to re-think the monstrosity of the "individual" within the laboratories of the study of 
religion. Though each author inhabits a specific disciplinary field, the special issue appropriates these disciplinary idioms into a wider problematic of these most fundamental constellations. In this respect, the special issue is experimental and comparative. The issue attempts to place scholars from anthropology, sociology, African-American history, Asian religions, philosophy, religious studies, critical theory, and ancient history alongside one another. It does so unashamedly in order to demonstrate the remarkable diversity enacted by the signifier, "religious;" as well as bring into conversation a series of interesting people working on remarkably engaging topics.

The special issue begins with the intriguing proposal of Bosco Bae, "Believing Selves and Cognitive Dissonance: Connecting Individual and Society via 'Belief'." Bae highlights how "belief" as an analytical tool and critical category of investigation for the study of religion has been a resurging topic of interest. After raising critical questions regarding the language and practice of "belief," specifically as they relate to assumed logics of "consistency," Bae argues for the utility and value of a "believing selves" framework, in conjunction with revisionist theories of cognitive dissonance, to advance the claim that beliefs are representations, as well as functions, of cultural history which bind individual and society.

Vaughn Booker, in a fascinating engagement with archival materials from prominent African American jazz musicians, comes next in his "Performing, Representing, and Archiving Belief: Religious Expressions among Jazz Musicians" These archives, Booker suggests, demonstrate rich sites for studying expressions of religious belief and daily religious practice in public and private arenas, in professional and personal capacities. Booker's focus is on print material from the archives of Edward Kennedy “Duke" Ellington (1899-1974) and Mary Lou Williams (1910-1981), and examines the articulations of beliefs in print and meaning-making practices of their routines. Ellington and Williams left records of their aspirations for a non-clerical religious authority and leadership, new formulations of religious community, and conceptions of quotidian writing tasks as practices with devotional value in the middle decades of the twentieth century. Booker has produced an important study of the making of a religious subjectivity of African and the complex political bricolage of religious interiority.

Josh Furnall, follows with his "Abraham Joshua Heschel and Nostra Aetate: shaping the Catholic reconsideration of Judaism during Vatican II." Although Nostra Aetate is only comprised of five short paragraphs, this document represents for Furnall a turning point not just for Catholic-Jewish relations, but also sketches the fundamental aims of embodying the Christian faith in a pluralistic age. Furnall re-examines crucial details in the back-story of the provenance of Nostra Aetate, arguing that recent events and scholarship within Catholic studies suffer from neglecting to attend to the role that Jewish people have played in the development of Catholic learning. In particular, Furnall considers how Rabbi Abraham Joshua Heschel played an important role during the Second Vatican Council, and provides an instructive example for contemporary Catholic-Jewish dialogue.

In "II's not the money but the love of money that is the root of all evil': social subjection, machinic enslavement and the limits of Christian social teaching," Marika Rose participates within contemporary theory's considerations of capitalism and its subject formation. Following Maurizio Lazzarato, who argues that contemporary capitalism functions through the central apparatuses of social subjection and machinic enslavement, Rose states that social subjection equips individuals with a subjectivity (identities, sexes, bodies, professions, etc.), with a sense of their own freedom. This machinic enslavement, as she refers to it, arises out of processes of production that function increasingly independently of human awareness or intention. Drawing on this analysis of the contemporary functioning of capitalism, her paper explores the concepts of individuals and society at work in recent Anglican social theology-particularly those of Eve Poole and Malcolm Brown-suggesting that, within the contemporary Church of England, mainstream attempts to reckon with political questions tend to understand the role of individual agency and ethical behaviour in ways which actually support existing social, political and economic structures rather than disrupting them.

Erin Johnston, draws on her fieldwork with an Integral Yoga studio and a Catholic prayer house in her "Spirituality as an Aspirational Identity." Johnston, sees within existing research on religious 
identity, especially from a narrative perspective, a tendancy to focus primarily on accounts of the past (especially on religious change) or on conceptions of religious identity in the present. The religious communities she surveys, however, provide not only a sense of identity and belonging in the present, they also promote a particular vision of the religious ideal: a way of being-in-the-world that adherents are (or ought to be) striving to achieve. From her fieldwork and interviews, Johnston finds that both communities defined themselves by three key characteristics: a sacred gaze, a simultaneous sense of presence and detachment, and a holistic style of identity management. In constructing and transmitting a shared vision of the "enlightened self," she argues, these organizations offer practitioners a highly desirable but elusive possible identity, which shapes practitioners' actions and self-understandings in the present. Johnston's original study calls attention to religious organizations as important suppliers of possible identities, and reveals the situated and contextual nature religious aspirations.

In another impressive study originating out of original field work, Sitna Quiroz considers "The Dilemmas of Monogamy: pleasure, discipline and the Pentecostal moral self in the Republic of Benin." Quiroz explores how Pentecostal teachings on marriage and the management of sexual pleasure contribute to shaping converts' moral selves. For Pentecostals, argues Quiroz, fidelity towards God, when single, and fidelity between partners, once married, is presented as the ideal model of partnership to which everyone should aspire. In a context where polygamous unions are socially accepted, a satisfactory sexual life restricted to the context of marriage is presented as the means to building successful monogamous unions. Sexual satisfaction might not always guarantee success, especially when people face problems of infertility. Quiroz suggests that the disciplinary regimes that these teachings promote, contribute to shaping new modes of intimacy, which are often at odds with extant social norms and ideals. The moral dilemmas which arise from this tension are key to understanding how Pentecostal Christianity shapes the moral self. Quiroz surveys how Pentecostals in Benin navigate and negotiate cultural continuities and discontinuities in relation to church authority and family life.

In "The Apparatus of Belief: Prayer, Technology, and Ritual Gesture," Anderson Blanton describes what he calls "the apparatus of belief," or the specific ways in which individual religious belief has become intimately related to tele-technologies such as the radio through a focus on the early history of a mass mediated ritual practice. More specifically, Blanton examines the performance of prayers during the Healing Waters Broadcast by the famous charismatic faith healer, Oral Roberts. Blanton's analysis of these healing prayers reveals the ways in which the old charismatic Christian gesture of manual imposition, or laying on of hands, took on new somatic registers and sensorial attunements when mediated, or transduced, through technologies such as the radio loudspeaker. Emerging from these mid-twentieth-century radio broadcasts, this technique of healing prayer popularized by Roberts has now become a key ritual practice and theological motif within the global charismatic Christian healing movement. Critiquing established conceptions of prayer in the disciplines of anthropology and religious studies, Blanton's fascinating essay repositions "belief" as a particular structure of intimacy between sensory capacity, media technology, and pious gesture.

George Gonzalez in his important, "Towards an Existential Archeology of Capitalist Spirituality," examines contemporary networked Capitalism, the discourse of "workplace spirituality," and the life history of one management reformer as case studies in an effort both to historicize experiences of neoliberal "spirituality," as an archaeology of knowledge might, while also attempting to account for intentionality and biography, as existential approaches would. Turning to work in contemporary critical theory which associates strident anti-humanism in social theory with the rise of neoliberal discourse, Gonzalez wager is that sustained attention to the ways in which personal and social history always entail one another and are mutually arising makes not only for better phenomenology but makes for better critical scholarship as well.

The peculiar evangelical work of Marilla Baker Ingalls, an American Baptist missionary to Burma from 1851-1902, is the subject of study by Alex Koloyanides in, "Show Us Your God:" The Power of Religious Objects in Nineteenth-Century Burma." By the time of her death in Burma at the age of 
seventy-five, Ingalls was known as one of the most successful Baptist evangelists among Burmese Buddhists. In an attempt to explicate the extraordinary dynamic within Ingalls' expanding Christian community, Koloyanides focuses on two prominent objects at the Baptist mission: a life-sized dog statue that Ingalls kept chained at the edge of her property and a massive banyan tree covered with biblical illustrations and revered by locals as the abode of divine beings. Koloyanides argues that these objects transformed Ingalls' American Baptist Christianity into a kind of Burmese religion that revolved around revered objects. Through an examination of the particular shrine practices that pulled people into the Baptist mission, this fascinating essay places these particular happenings into the larger context of religious encounter, conflict, and representation in colonizing Burma.

In "Women and Spirits," Candi Cann examines the intersection of women and alcohol in funerals and death memorialization through a comparative analysis in European and Chinese culture. Two central religious texts regarding the roles of women and alcohol in Christianity and Chinese religious thought are examined. Cann then contextualizes her ethnographic work by turning to the historical and textual background of current death rituals in Mexican Catholicism, Chinese religions, and American Southern Baptist funerals. In this impressive mixed-methods essay, Cann argues that both alcohol and temperance are used as a way to forge, cement, and create gender identity and construct alternate discourses of inclusivity in afterlife conceptions.

Michael J. Thate, in "Messianic Time and Monetary Value," turns to recent materialist messianic readings, and brings them into conversation with Walter Benjamin's notion of messianic time as outlined particularly in his Theses on the Philosophy of History. Messianic time is read stylistically with Benjamin's Sonnets as subject divestment from historical time. Thate places the trope of messianic time as the divestment of the subject from historical time into a brief consideration on monetary value's relationship market time. In this essay, Thate pushes for a rereading of Benjamin's notion of messianic time as divestment from historical time, thus breaking the uneven distribution of time, accumulation, and monetary value of market time.

Devin Singh, in his provocative, "Speculating the Monetary Subject: Georg Simmel on Human Value," initiates an inquiry into the sources and frameworks of value used to denote human subjects within modernity. In particular, Singh considers the conflation of monetary, legal, and theological registers employed to demarcate human worth. Singh, in a careful reading of Simmel, draws from his speculative genealogy of the money equivalent of human values, in order to establish a spectrum of ascriptions from specifically quantified to infinite human value. Predications of infinite human value, Singh argues, require and imply quantified—and specifically monetary-economic - human value. As such, cost and worth, economically and legally defined, provide a foundation for subsequent eternal projections in a theological imaginary. The interventionist potential of claims to infinite or unquantifiable human value in attempts to resist the contemporary financialization of human life and society in Singh's analysis are thus called into question.

Recalling Mary Shelley's "thrilling horror," itself not far removed from Rudolph Otto's century-later mysterium fascinans, we ponder the echoing resonances between Frankenstein's protest against masterly creativity, and, perhaps, Luther's longing for the freedom of the Christian amidst institutional constraints. Such emotional waves bring their own pressure to bear upon Religion, Identity, and Belief, and whether tectonic or merely mildly intrusive, they rise from the dissonances sensed by any reflective self-pervaded by music, strangely familiar Jewish narratives, or visionary gazing after perfection. The diverse worldviews that kaleidoscope through these essays call for seeking our own enchanted garden where, sexuality, holy hands, alongside symbolic animals, plants, and alcohol's mystification, all lurk to surprise. Less nuanced are those other forces of gender and money that sustain or subvert our identities in life's possibilities, all cusped by mortality. Just as the biblical Acts, energized by its own Holy Ghost engagement, set money as the soteriological medium of community authenticity, martyrdom or betrayal, so do our essays, in their own small way, post a challenge for collaborative ponderings over the monstrosities of religion, identity, and belief. 
Conflicts of Interest: The authors declare no conflict of interest.

\section{References}

Shelley, Mary. 1998a. Introduction. In Frankenstein. Oxford: Oxford University Press, pp. 5-11, First published 1817. Shelley, Mary. 1998b. Frankenstein. Oxford: Oxford University Press, First published 1817. 